\title{
Processing separated digestate by vermicomposting technology using earthworms of the genus Eisenia
}

\author{
A. Hanc $\cdot$ F. Vasak
}

Received: 26 September 2013/Revised: 6 December 2013/Accepted: 11 January 2014/Published online: 30 January 2014 (C) Islamic Azad University (IAU) 2014

\begin{abstract}
In the current study, pre-composting and subsequent vermicomposting of separated digestate (also called separated biogas plant slurry) were verified to improve its properties for use as a soil conditioner. Increasing the proportion of straw in combination with separated digestate had a positive effect on reducing both weight and volume during vermicomposting. The $\mathrm{pH}$ value decreased and was found to be between 7.3 and 7.7 in the final vermicomposts. Due to a loss in organic matter, the total content of macro-elements increased at the end of vermicomposting with the exception of calcium. Similarly, the available contents of phosphorus and potassium increased, which was positive in terms of the use of vermicompost for agricultural purposes. After 5 months of vermicomposting, the earthworm biomass increased from 282 to $896 \%$ depending on the treatment. The best results were achieved during the vermicomposting of a mixture of straw (25 vol \%) with separated digestate (75 vol \%).
\end{abstract}

Keywords Biogas plant slurry · Pre-composting ·

Vermicompost - Straw · Sustainable treatment

\section{Introduction}

The processing of bio-waste by anaerobic digestion is now widespread in the world. In the Czech Republic, biogas production has a long tradition. The first biogas plants were constructed in the $1960 \mathrm{~s}$. However, a boom in the number

A. Hanc $(\bowtie) \cdot$ F. Vasak

Department of Agro-Environmental Chemistry and Plant

Nutrition, Czech University of Life Sciences Prague,

Kamycka 129, 16521 Prague 6, Czech Republic

e-mail: hanc@af.czu.cz of biogas plants in this country started early in 2007, and more than 480 biogas units are currently in operation (CzBA 2013). Nevertheless, there is still considerable potential for the use of biogas technology. Together with biogas, anaerobic digestion produces a residual material called digestate or biogas plant slurry. An accumulation of biogas plants in certain regions might lead to an oversupply of digestate, especially in regions with intensive livestock farming or fermentation of organic residues and bio-waste. If the agricultural area is too small for adequate use of the digestate, surplus material can be transported to regions with nutrient deficits. The transportation of digestate could cause logistical problems (Rehl and Müller 2011). Therefore, adequate treatment of digestate must be addressed.

Composting using earthworms (vermicomposting) is an appropriate method to improve the parameters of digestate as a fertilizer. The vermicomposting process involves the biooxidation and stabilization of organic material by the joint action of earthworms and microorganisms. Although it is the microorganisms that biochemically degrade the organic matter, earthworms are the crucial drivers of the process as they promote aeration conditions, fragment the substrate, and thereby drastically increase the microbial activity (Dominguez and Edwards 2011a, b). Thus, vermicomposting gives a higher-quality end product (vermicastings) than composting due to the enzymatic and microbial activities that occur during the process (Bajsa et al. 2003). This product is nutrient rich and contains especially high-quality humus, plant growth hormones, enzymes, and substances that are able to protect plants against pests and diseases (Sinha et al. 2010a, b). Prior to the vermicomposting process, it can be appropriate to assign pre-composting (thermophilic composting), which comprises a short period of high temperature, facilitating mass reduction, waste stabilization, and pathogen reduction (Nair et al. 2006; Frederickson et al. 2007). 
Table 1 Selected agrochemical parameters of the materials used

\begin{tabular}{lllllllllll}
\hline & Dry matter $(\%)$ & $\mathrm{pH} / \mathrm{H}_{2} \mathrm{O}$ & $\mathrm{EC}(\mathrm{mS} / \mathrm{cm})$ & Vol. solids $(\%)$ & $\mathrm{N}_{\text {tot. }}(\%)$ & $\mathrm{C} / \mathrm{N}$ & $\mathrm{P}_{\text {tot. }}(\%)$ & $\mathrm{K}_{\text {tot. }}(\%)$ & $\mathrm{Ca}_{\text {tot. }}(\%)$ & $\mathrm{Mg}_{\text {tot. }}(\%)$ \\
\hline $\begin{array}{l}\text { Separated } \\
\text { digestate }\end{array}$ & 24 & 8.8 & 3.0 & 84 & 1.8 & 23 & 0.61 & 1.62 & 1.27 & 0.38 \\
\begin{tabular}{l} 
Straw \\
\hline
\end{tabular} & 70 & 7.4 & 1.5 & 91 & 0.6 & 75 & 0.02 & 0.47 & 0.28 & 0.03 \\
\hline
\end{tabular}

The aim of the current study was to assess the viability of vermicomposting of solid fraction of digestate (separated digestate) on the basis of change in physico-chemical properties and earthworm biomass. Little is known regarding the vermicomposting of separated digestate originating from biogas plants located in temperate climates, and this work provides some of the first experimental results. The research carried out throughout the study was done in the Czech University of Life Sciences Prague, Czech Republic in 2012.

\section{Materials and methods}

Feedstocks

Digestate after dewatering from an agricultural biogas station and wheat straw as a bulking agent were used in the experiment. Their agrochemical parameters are shown in Table 1.

For the experiment, dry wheat straw was soaked in water for $4 \mathrm{~h}$ to enhance the absorption capacity and thus aid in faster decomposition. Thus, the dry matter content of the straw was decreased on $24 \%$. The materials used were mixed and subjected to pre-composting and vermicomposting (Table 2).

Pre-composting process

Pre-composting was carried out in a system for the fermentation of solid biomass which was placed in a room at $25{ }^{\circ} \mathrm{C}$. The system consisted of:

1. $70 \mathrm{~L}$ laboratory fermenters with perforated stokers enhanced by $40-\mathrm{mm}$-thick polyethylene foam insulation to reduce heat loss.

2. A compressor equipped with an output connected to the electromagnetic valve associated with the flow meter. Each flow meter was assigned to one fermenter. The outlet of each flow meter was connected to a fourway valve, which pushed air into the composted materials from the bottom. Hoses from the outlets lead to the top of the fermenter and into the condensing flask as well. To reduce non-homogenous aeration by preferential flow channels, which may occur when a low volume of air is brought into the system, the air was blown in discontinually, but in regular blowing
Table 2 Proportion of straw and separated digestate in the treatments (in vol \%) and types of processing

\begin{tabular}{|c|c|c|}
\hline Treat & Feedstocks ( $\%$ by volume) & Type of processing \\
\hline 1 & Straw $(50)+$ digestate $(50)$ & $\begin{array}{l}\text { Pre-composting and } \\
\text { composting } \\
\text { without } \\
\text { earthworms }\end{array}$ \\
\hline 2 & Straw $(75)+$ digestate $(25)$ & $\begin{array}{l}\text { Pre-composting and } \\
\text { vermicomposting }\end{array}$ \\
\hline 3 & Straw $(50)+$ digestate $(50)$ & $\begin{array}{l}\text { Pre-composting and } \\
\text { vermicomposting }\end{array}$ \\
\hline 4 & Straw $(25)+$ digestate $(75)$ & $\begin{array}{l}\text { Pre-composting and } \\
\text { vermicomposting }\end{array}$ \\
\hline 5 & Straw $(0)+$ digestate $(100)$ & $\begin{array}{l}\text { Pre-composting and } \\
\text { vermicomposting }\end{array}$ \\
\hline
\end{tabular}

cycles. The mixtures were batchwise aerated for $5 \mathrm{~min}$ in every half an hour over a period of 2 weeks in a volume of $4 \mathrm{~L}$ air $\min ^{-1}$. On the basis of the previous experiences of Hanc et al. (2012), this aeration level was usually sufficient to achieve the optimal parameters of the composting process. Very low aeration levels are insufficient for effective composting, yet on the other hand, increased aeration merely increases the cooling of the composted materials.

\section{Vermicomposting process}

For vermicomposting, a specially adapted laboratory with controlled conditions (temperature $20{ }^{\circ} \mathrm{C}$, relative humidity $80 \%$, ventilation for 15 min every $12 \mathrm{~h}$ ) was used. A $13-\mathrm{L}$ batch of aerobically pre-composted material was manually mixed with $3 \mathrm{~L}$ of beef manure substrate containing a total of 600 earthworms of the genus Eisenia (treatments 2-5). In the case of control treatment 1 , the beef manure substrate was used without earthworms. The mixture was placed into a plastic bowl with a perforated bottom which was equipped with irrigation and temperature measurement. The bowl measured $40 \times 40 \times 18 \mathrm{~cm}$. The covered bowls were put into a metal rack. Each treatment was carried out in triplicate. Before sampling, the eventual leachate that was captured in a stainless bowl was returned to the vermicomposted material to achieve a closed loop. A sample of $200 \mathrm{~g}$ was collected from each bowl each month 
Fig. 1 Description of the process

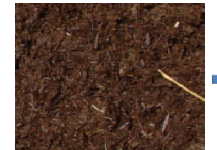

Separated digestate

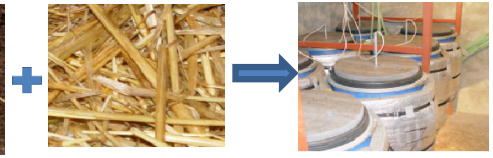

Wheat straw
Pre-composting

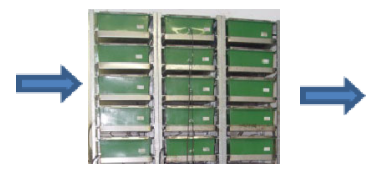

Vermicomposting

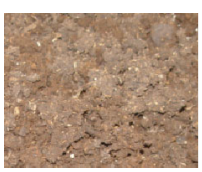

Vermicompost during the 5-month study period. The earthworms were sorted out. The resulting samples were dried at room temperature and ground to ensure homogeneity.

Description of the whole studied process is illustrated in Fig. 1.

\section{Analytical methods}

Measurements of $\mathrm{pH}$ and electrical conductivity were conducted on samples mixed with deionized water (1:10 w/v dry basis) by WTW pH $340 \mathrm{i}$ and Testo 240, respectively. The concentration of volatile solids was established from ignition loss in samples kept at $550{ }^{\circ} \mathrm{C}$ for $12 \mathrm{~h}$. Organic carbon was determined by dichromate oxidation in sulfuric acid solution and total nitrogen by the Kjeldahl method using a Gerhardt analytical system Vapodestmanager device. Total element contents ( $\mathrm{P}, \mathrm{K}, \mathrm{Ca}$, and $\mathrm{Mg}$ ) in the digests were obtained by pressurized wet-ashing $\left(\mathrm{HNO}_{3}+\mathrm{HCl}+\mathrm{HF}\right)$ with microwave heating using an Ethos 1 system (MLS GmbH, Germany). Contents of N$\mathrm{NH}_{4}{ }^{+}$and $\mathrm{N}-\mathrm{NO}_{3}{ }^{-}$in 1:10 (w/v) $0.01 \mathrm{~mol} \mathrm{~L}^{-1} \mathrm{CaCl}_{2}$ extracts were measured colorimetrically using the SKALAR SANPLUS SYSTEM ${ }^{\circledR}$. The available contents of elements in materials were ascertained in 1:20 (w/v) $0.11 \mathrm{~mol} \mathrm{~L}^{-1} \mathrm{CH}_{3} \mathrm{COOH}$. The concentrations of elements were determined using inductively coupled plasma optical emission spectrometry (ICP-OES, VARIAN VistaPro, Varian, Australia) with axial plasma configuration.

\section{Results and discussion}

Pre-composting of feedstock

It is evident from Fig. 2 that the total fresh mass lost from each of the treatments during the pre-composting phase was indirectly dependent on increasing the proportion of separated digestate in the mixtures. The highest loss $(15 \%)$ was recorded in treatment 2 .

The temperature courses for the individual treatments in the fermenters are shown in Fig. 3. The maximum temperature ranged from 45 to $55^{\circ} \mathrm{C}$ in fermenters $1-4$. The separated digestate itself reached a lower maximum temperature for a longer period of time because most of the

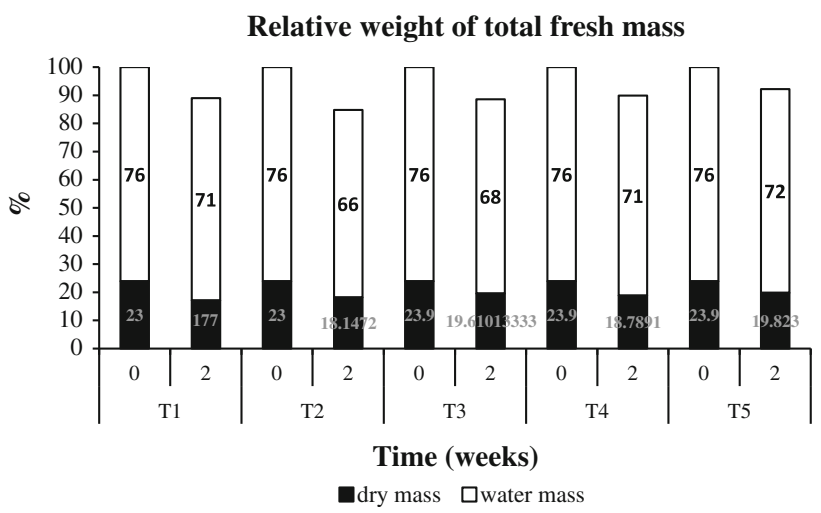

Fig. 2 Relative weight of total fresh mass in \% during precomposting of feedstock

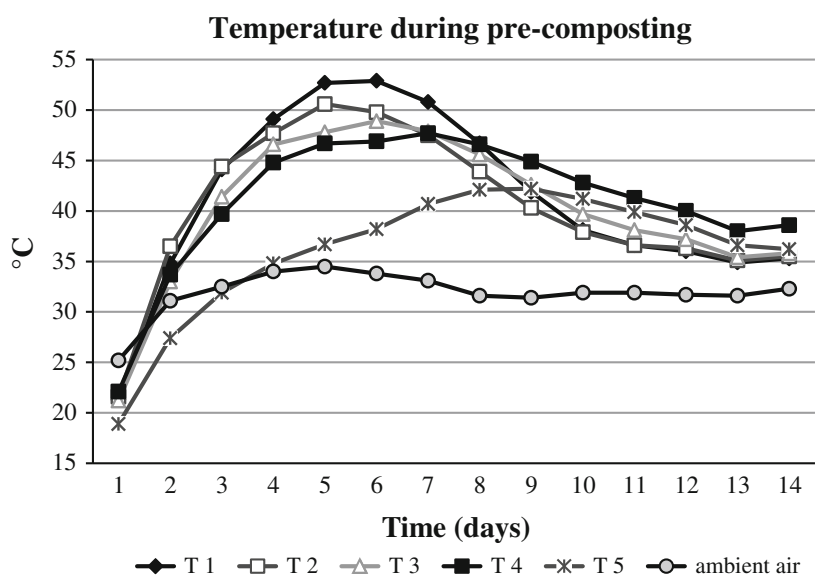

Fig. 3 Course of temperature $\left({ }^{\circ} \mathrm{C}\right)$ during pre-composting in individual treatments

labile organic matter were probably lost during anaerobic digestion (Kolar et al. 2008). The pre-composting of mixtures was shown to be an effective method of preventing increases in temperature during subsequent vermicomposting, which positively affected the survival of the earthworms. In addition, after 14 days of fermentation, the material was also softer, more workable, and palatable for earthworms. Differences in properties between pre-composted and non-pre-composted feedstock are described in Hanc and Pliva (2013) and Sinha et al. (2002). 


\section{Vermicomposting}

Based on literature and practical experience, the temperature for the development of earthworm populations should not exceed $25^{\circ} \mathrm{C}$ (Sinha et al. 2008). The adverse effect of high temperatures on earthworms is not only direct but also indirect, as a high temperature increases the microbial activity in the substrate, which is reflected in the increased consumption of oxygen. This is especially true for a large volume of material. This phenomenon may negatively affect the survival of earthworms (Dominguez and Edwards 2011a, b). After loading into a bowl, the temperature of the precomposted mixtures increased slightly (from ambient temperature to $22-23{ }^{\circ} \mathrm{C}$ ). Thereafter, the temperature gradually decreased and leveled off to ambient air temperature.

There is an effort to reduce the weight and especially the volume of vermicomposting material. In the present trial, increasing the proportion of straw in combination with separated digestate had a positive effect on reducing both the weight and volume during vermicomposting. Among the treatments, the mixture with straw $(75 \mathrm{vol} \%)$ and digestate (25 vol\%) showed the greatest decrease in volume (73\%). However, the change in weight and volume was affected by moistening of the material and the activity of earthworms.

The $\mathrm{pH}$ value is one of the most important factors affecting the vermicomposting process (Gajalakshmi and Abbasi 2004). As it is evident from Fig. 4, an initial upward trend for treatments 1 and 2 was found.

This could be caused by the prime consumption of organic acids by microorganisms. On the contrary, the $\mathrm{pH}$ rapidly decreased in the case of treatments 3, 4, and 5. After 3 months, the $\mathrm{pH}$ decreased in all of the treatments. The mineralization of organic compounds and thus an increase in the contents of $\mathrm{CO}_{2}, \mathrm{NO}_{3}{ }^{-}$, organic and humic acids can play an important role in the decline of the $\mathrm{pH}$ (Garg et al. 2006; Suthar and Singh 2008). The optimal pH during vermicomposting is recommended to be 7.5-8.0 (Garg and Gupta 2011). In the current experiment, the $\mathrm{pH}$ ranged from 8.4 to 7.3. The high $\mathrm{pH}$ of the initial vermicomposted material was caused by the $\mathrm{pH}$ of the original separated digestate (8.8).

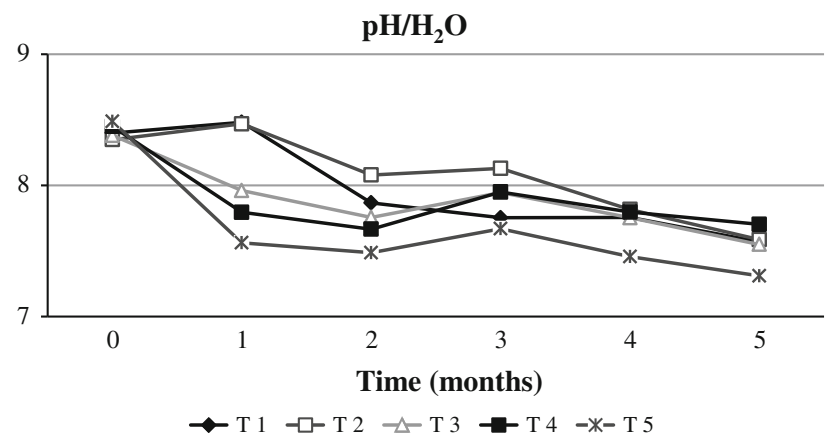

Fig. 4 Course of $\mathrm{pH} / \mathrm{H}_{2} \mathrm{O}$ during vermicomposting
The electrical conductivity (EC) reflects the salinity of an organic amendment. A high salt concentration may cause phytotoxicity problems, and therefore the EC is a good indicator of the suitability and safety of compost or vermicompost for agricultural purposes (Lazcano et al. 2008). The EC increased during the experiment in all of the treatments. This trend was related to the decreased volume and weight of the vermicomposted materials. The values ranged from 2.3 to $2.4 \mathrm{mS} / \mathrm{cm}$ at the beginning, and $5.2-8.1 \mathrm{mS} / \mathrm{cm}$ at the end of the trial. The increased proportion of separated digestate in the mixture resulted in a higher EC. The increase in EC might have been due to the reduction in the weight of organic matter and the release of different mineral salts such as phosphate, ammonium, and potassium (Garg et al. 2006; Yadav and Garg 2011). Similarly, an increase in the EC was recorded in a parallel experiment involving vermicomposting of garden biowaste and sewage sludge, where the EC increased from 1.6 to $2.7 \mathrm{mS} / \mathrm{cm}$, to between the range of $3.0-6.8 \mathrm{mS} / \mathrm{cm}$ (Hanc and Pliva 2012).

The loss of organic matter caused the total contents of most macro-elements [phosphorus $(\mathrm{P})$, potassium $(\mathrm{K})$, and magnesium $(\mathrm{Mg})]$ to increase during vermicomposting (Chaudhuri et al. 2000). The average ratio of the final and initial content of elements in all five treatments increased in the following order: $\mathrm{P}(124 \%), \mathrm{K}(154 \%)$, and $\mathrm{Mg}$ $(185 \%)$ as it is illustrated in Fig. 5a-c. Increase of total P in treatment 1 was the highest among treatments. It could be caused by uptake and absorption of $\mathrm{P}$ in earthworm bodies (treatments 2-5) that were sorted out before analyses of samples. In addition, standard deviation in treatment 1 was twice as high compared to vermicomposting treatments. The calcium $(\mathrm{Ca})$ content was the exception (Fig. 5d). This decrease could be explained by the consumption of $\mathrm{Ca}$ by earthworms (treatments 2-5). $\mathrm{Ca}$ is an important mineral element in biology for earthworms, and it is used mainly as a building substance of earthworm tissue and for biodegradation activities in earthworm bodies (Sinha et al. 2010a, b). Similarly, the total Ca contents in the final casts were slightly lower than in the initial feed mixtures of solid textile mill sludge with cow dung in different ratios in a 90-day vermicomposting experiment (Kaushik and Garg 2003). On the other hand, Orozco et al. (1996) reported an increase in the total Ca content after the ingestion of coffee pulp waste by earthworms. No significant increases in $\mathrm{Ca}$ have been reported in the vermicomposting of cow manure, where excess water was drained through the mass (Elvira et al. 1996). The differences in the results could be attributed to the differences in the chemical nature of the initial raw materials.

Available content is only part of total content and is strongly affected by biochemical properties. During the course of our study, the available content of some nutrients 
(a)

Total content of phosphorus (in relative \%)

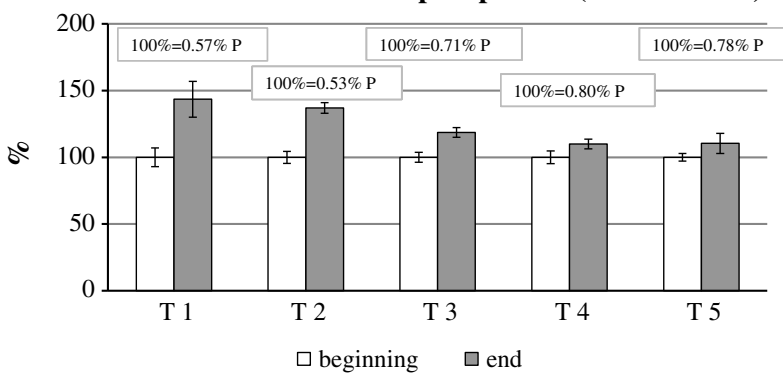

(b)

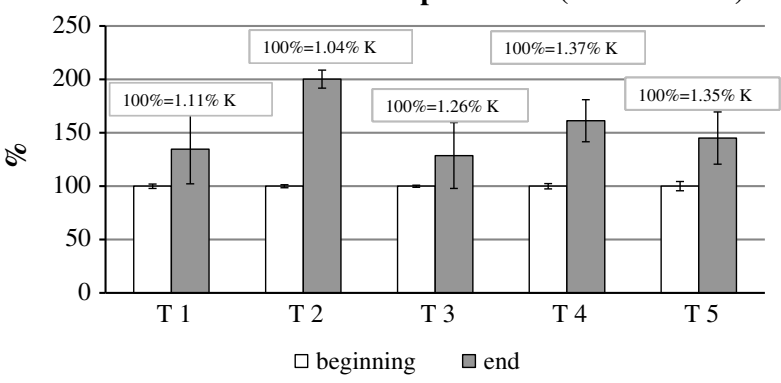

(c)

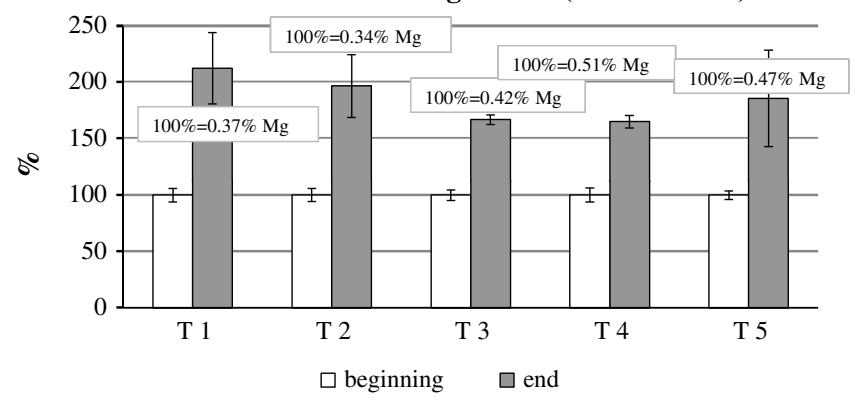

(d)

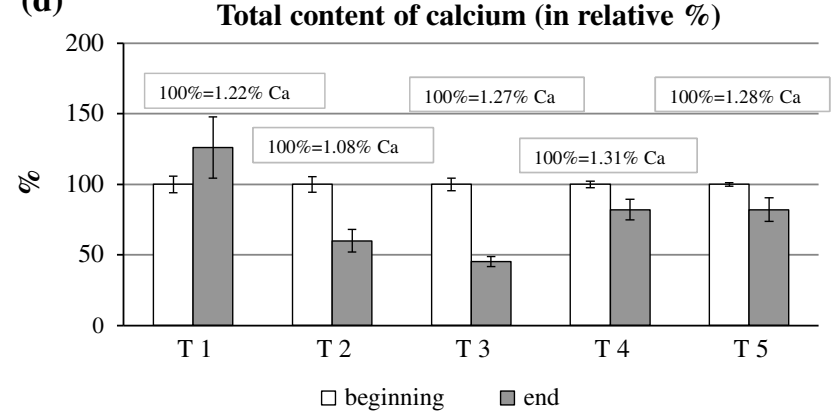

(e)

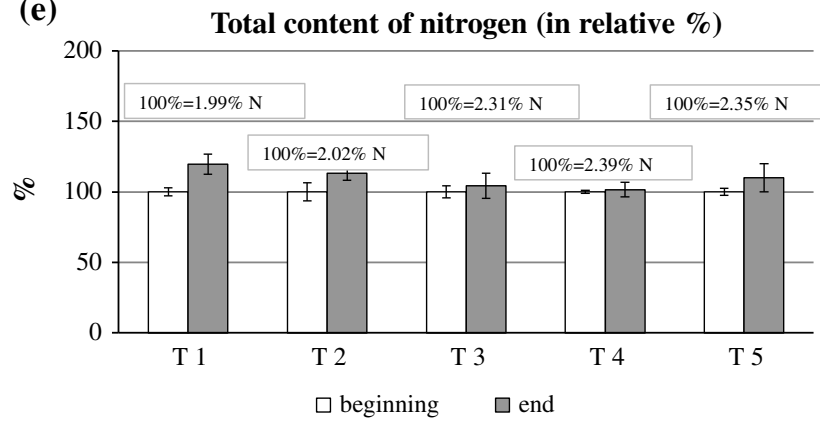

Fig. 5 Total contents of phosphorus (a), potassium (b), magnesium (c), calcium (d), and nitrogen (e) at the beginning and at the end of vermicomposting $(\mathrm{mg} / \mathrm{kg})$

increased, which was positive in terms of the use of vermicompost for agricultural purposes. Substantial increases were found especially for available $\mathrm{P}$ and $\mathrm{K}$, which increased from an initial 6,000 and $1,400 \mathrm{mg} / \mathrm{kg}$ to final concentrations of 8,000 and 4,700 mg/kg, respectively (Table 3). Garg et al. (2012) reported an increase in available $\mathrm{P}$ from an initial $6,400 \mathrm{mg} / \mathrm{kg}$ to a final content of $9,800 \mathrm{mg} / \mathrm{kg}$ in vermicompost originally containing $75 \%$ fresh anaerobically digested biogas plant slurry and $25 \%$ food industry sludge. Lee (1985) suggests that the passage of organic matter through the gut of worms results in $\mathrm{P}$ being converted into forms which are more bioavailable to plants. This is done partly by enzyme phosphatases present in the gut of the worm and partly by the release of phosphate solubilizing microorganisms in the worm cast (Satchel and Martin 1984). Acid production by the microorganisms seems to be the prime mechanism for solubilizing the insoluble $\mathrm{K}$ (Garg et al.
2006). The enhanced number of microflora present in the gut of earthworms in the case of vermicomposting might have played an important role in this process and increased the $\mathrm{K}$ content (Sharma 2003). On the other hand, the contents of available $\mathrm{Ca}$ and $\mathrm{Mg}$ decreased at the end of vermicomposting by 20 and $85 \%$, respectively.

The $\mathrm{C} / \mathrm{N}$ ratio is affected mainly by the feedstocks utilized. Ndegva and Thompson (2000) dealt with the effects of the $\mathrm{C} / \mathrm{N}$ ratio on the vermicomposting of biosolids. They concluded that the best initial $\mathrm{C} / \mathrm{N}$ ratio for feeding of earthworms is $25: 1$. In this trial, the initial $\mathrm{C} / \mathrm{N}$ ratios of the mixtures used for vermicomposting was from 17 to 20, depending on the increased volume of the straw in the mixtures. The low values were caused mainly by the pre-composting of digestate and straw. A slight decline in the $\mathrm{C} / \mathrm{N}$ ratio was found during vermicomposting (14-16). Similarly, a decline in the $\mathrm{C} / \mathrm{N}$ ratio was found in an experiment on the 
Table 3 Available content of phosphorus, potassium, calcium, and magnesium (in $\mathrm{mg} / \mathrm{kg}$ ) in initial feed mixtures and vermicomposts (mean $\pm \mathrm{SD}, n=3$ )

\begin{tabular}{llcl}
\hline Element & Treatment & Initial mixture & Vermicompost \\
\hline $\mathrm{P}$ & 1 & $5,415 \pm 588$ & $8,267 \pm 251$ \\
& 2 & $5,120 \pm 199$ & $7,072 \pm 262$ \\
& 3 & $6,172 \pm 220$ & $8,276 \pm 283$ \\
& 4 & $6,391 \pm 107$ & $8,774 \pm 90$ \\
$\mathrm{~K}$ & 5 & $6,677 \pm 222$ & $8,328 \pm 618$ \\
& 1 & $1,328 \pm 88$ & $7,359 \pm 818$ \\
& 2 & $1,356 \pm 349$ & $6,290 \pm 973$ \\
& 3 & $1,384 \pm 38$ & $4,977 \pm 1,331$ \\
& 4 & $1,696 \pm 29$ & $2,438 \pm 243$ \\
$\mathrm{Ca}$ & 5 & $1,542 \pm 236$ & $2,496 \pm 1,301$ \\
& 1 & $10,730 \pm 958$ & $6,838 \pm 731$ \\
& 2 & $10,930 \pm 327$ & $6,586 \pm 738$ \\
& 3 & $10,051 \pm 510$ & $8,661 \pm 258$ \\
& 4 & $10,651 \pm 348$ & $9,860 \pm 353$ \\
$\mathrm{Mg}$ & 5 & $9,955 \pm 684$ & $8,399 \pm 557$ \\
& 1 & $4,787 \pm 243$ & $843 \pm 25$ \\
& 2 & $3,858 \pm 1,289$ & $844 \pm 22$ \\
& 3 & $5,371 \pm 228$ & $704 \pm 26$ \\
& 4 & $6,513 \pm 1,366$ & $782 \pm 215$ \\
& 5 & $6,808 \pm 1,131$ & $1,034 \pm 158$ \\
\hline & & &
\end{tabular}

vermicomposting of cow dung and vegetable waste, with a final $\mathrm{C} / \mathrm{N}$ ratio between 15 and 19 (Garg and Gupta 2011).

Slightly higher contents of total nitrogen (Fig. 5e) were found at the end of vermicomposting (compared to beginning by $8 \%$ ). A look at the soluble portions of nitrogen indicates that the initial mixtures, especially treatments 4 and 5 , contained high amounts of ammonium nitrogen ( $\mathrm{N}-$ $\mathrm{NH}_{4}{ }^{+}$) as it is illustrated in Fig. 6a. Generally, separated digestate has a high content of $\mathrm{N}-\mathrm{NH}_{4}{ }^{+}$due to the mineralization of organic nitrogen (Tambone et al. 2010). Therefore, the contents of $\mathrm{N}-\mathrm{NH}_{4}{ }^{+}$increased proportionally with the increased amount of separated digestate in the mixtures. After 1 month of vermicomposting, the content of $\mathrm{N}-\mathrm{NH}_{4}{ }^{+}$ decreased to about $100 \mathrm{mg} / \mathrm{kg}$. The decline was probably caused by volatilization, incorporation into the tissues of earthworms, and nitrification (Chaudhuri et al. 2000). The treatments that contained a high initial content of $\mathrm{N}-\mathrm{NH}_{4}{ }^{+}$ exhibited strong nitrification and thus high contents of nitrate nitrogen $\left(\mathrm{N}-\mathrm{NO}_{3}{ }^{-}\right)$as it is shown in Fig. 6b. The proportion of $\mathrm{N}^{-\mathrm{NO}_{3}}{ }^{-}$constituted up to $30 \%$ of the total $\mathrm{N}$ at the end of the vermicomposting treatment.

As mentioned previously and as can be seen from the results achieved above, the substantial differences between compost and vermicompost are not particularly in basic physico-chemical properties, but in other parameters related to earthworms. Thus, further research should be
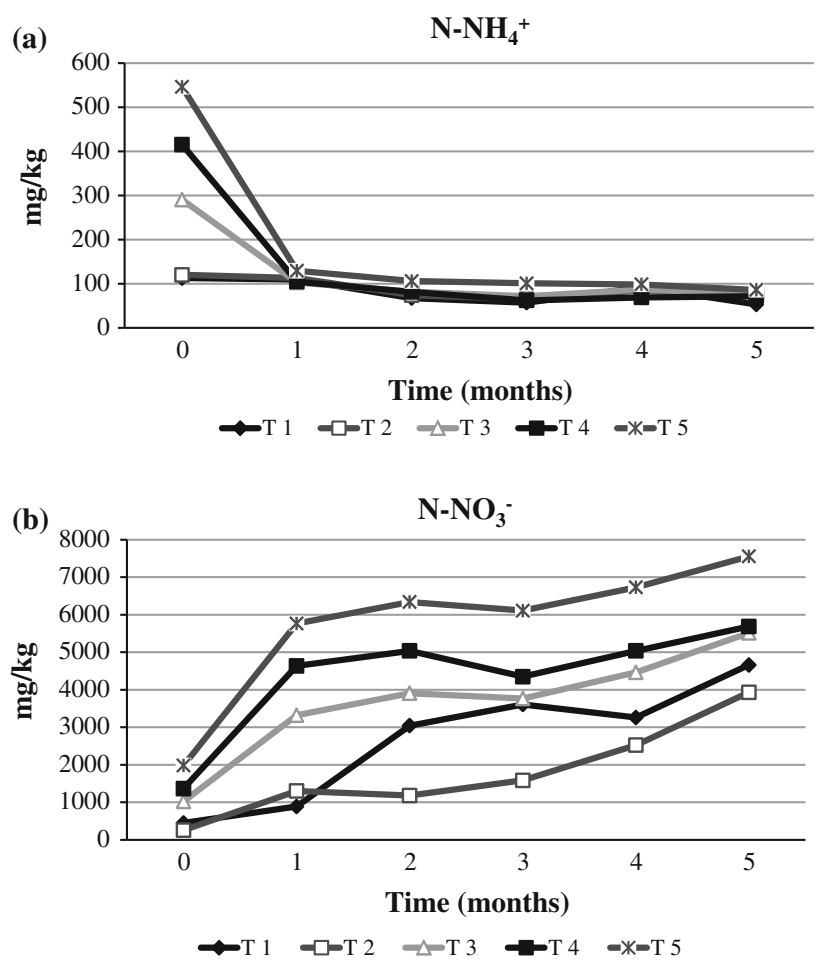

Fig. 6 Course of mineral forms of nitrogen such as $\mathrm{N}-\mathrm{NH}_{4}{ }^{+}$(a) and $\mathrm{N}-\mathrm{NO}_{3}{ }^{-}$(b) during vermicomposting $(\mathrm{mg} / \mathrm{kg})$

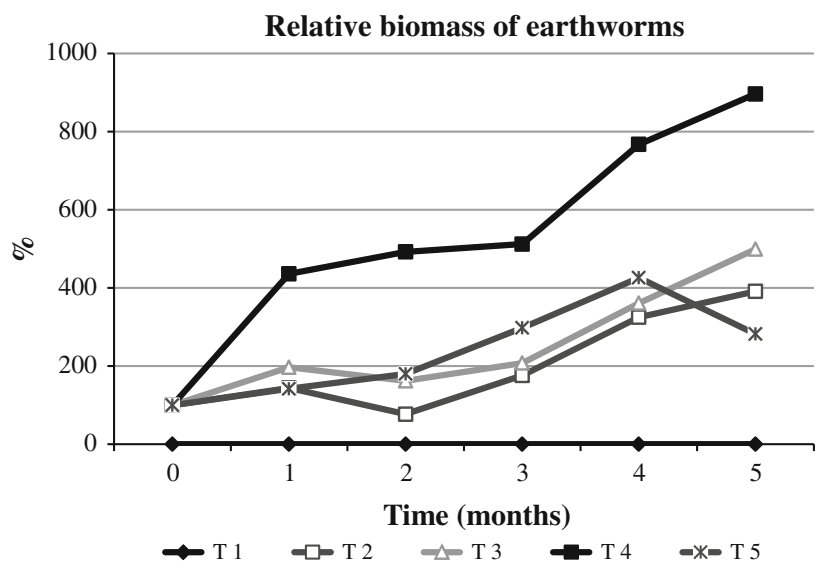

Fig. 7 Relative biomass of earthworms related to $1 \mathrm{~L}$ of material (\%)

focused on the evaluation of vermicompost from separated digestate in terms of the quality of the organic matter (humic and fulvic acids), enzyme activity, microbial community, and plant growth hormones such as indole acetic acids, gibberellins, and cytokinins.

Earthworm biomass is a product of the amount and weight of earthworms related to the weight or volume of the vermicomposted material. Fig. 7 illustrates that the development of the relative biomass of earthworms related to $1 \mathrm{~L}$ of material varied in the individual treatments. There was 
significant fluctuation of the earthworm biomass in treatment 2 . This fact could be justified by the high proportion of straw. It was very difficult to take representative samples because earthworms were deployed very irregularly, and they formed clusters on the remains of straw stalks. Fluctuation was not so marked in treatment 3. An increase in earthworm biomass during the duration of experiment was recorded only for treatment 4 . The earthworm biomass increased ninefold at the end compared with the beginning. The earthworm biomass decreased in treatment 5 after 4 months, which was probably caused by the depletion of suitable substances for earthworms in the separated digestate itself. The reason for this could be that the high portion of carbon substances available for microorganisms, and earthworms was most likely converted into biogas during anaerobic fermentation. In an experiment that involved vermicomposting of filter mud procured from a sugar mill, the increase in the weight of the earthworm biomass ranged from 60 to $70 \%$ after 45 days of processing (Khwairakpam and Bhargava 2009a). An increase of 10-28\% in the earthworm biomass was observed after 45 days of vermicomposting of sewage sludge (Khwairakpam and Bhargava 2009b). In another study, the maximum individual biomass was recorded after 4 weeks of vermicomposting of vegetable greenhouse waste with the addition of cow dung and straw (Fernández-Gómez et al. 2010). Suthar and Singh (2008) found the maximum individual biomass in month four of a 5-months-long study involving the vermicomposting of domestic waste. The differences referred to in these studies are mainly attributed to the type of bio-waste, its treatment, the amount of earthworms used, and the conditions of the experiments.

\section{Conclusion}

The study proved that the use of separated digestate as feedstock for vermicomposting can potentially help to convert this material into a value added product. The best results were achieved with a mixture of separated digestate with straw in the volume ratio of $3: 1$. The resulting vermicomposts had optimal $\mathrm{pH}$ values and $\mathrm{C} / \mathrm{N}$ ratios for agricultural purposes. They were rich in total and available contents of macro-elements, especially $\mathrm{P}$ and $\mathrm{K}$, and in the $\mathrm{N}-\mathrm{NO}_{3}{ }^{-}$ form of nitrogen.

Acknowledgments Financial support for these investigations was provided by NAZV project No. QI91C199 of the Ministry of Agriculture of the Czech Republic.

\section{References}

Bajsa O, Nair J, Mathew K, Ho GE (2003) Vermiculture as a tool for domestic wastewater management. Water Sci Technol 48:125-132
Chaudhuri PS, Pal TK, Bhattacharjee G, Dey SK (2000) Chemical changes during vermicomposting (Perionyx excavatus) of kitchen wastes. Trop Ecol 41:107-110

CzBA (2013) National technological platform for biogas. http://www. czba.cz/en.html (cit. 10 Jun 2013)

Dominguez J, Edwards CA (2011a) Biology and ecology of earthworm species used for vermicomposting. In: Edwards CA, Arancon NQ, Sherman R (eds) Vermiculture technology. CRC Press, Taylor \& Francis Group, Boca Raton, pp 27-40

Dominguez J, Edwards CA (2011b) Relationships between composting and vermicomposting. In: Edwards CA, Arancon NQ, Sherman R (eds) Vermiculture Technology. CRC Press, Taylor \& Francis Group, Boca Raton, pp 11-25

Elvira C, Dominguez J, Mato S (1996) The growth and reproduction of Lumbricus rubellus and Dendrobena rubida in cow manure. Mixed cultures with Eisenia Andrei. Appl Soil Ecol 5:97-103

Fernández-Gómez MJ, Romero R, Nogales R (2010) Feasibility of vermicomposting for vegetable greenhouse waste recycling. Bioresour Technol 101:9654-9660

Frederickson J, Howell G, Hobson AM (2007) Effect of precomposting and vermicomposting on compost characteristics. Eur J Soil Biol 43:S320-S326

Gajalakshmi S, Abbasi SA (2004) Earthworms and vermicomposting. Indian J Biotechnol 3:486-494

Garg VK, Gupta R (2011) Optimization of cow dung spiked preconsumer processing vegetable waste for vermicomposting using Eisenia fetida. Ecotoxic Environ Safe 74:19-24

Garg P, Gupta A, Satya S (2006) Vermicomposting of different types of waste using Eisenia foetida: a comparative study. Bioresour Technol 97:391-395

Garg VK, Suthar S, Yadav A (2012) Management of food industry waste employing vermicomposting technology. Bioresour Technol 126:437-443

Hanc A, Pliva P (2012) Vermicomposting of garden biowaste and sewage sludge. Waste Forum 2012:103-110

Hanc A, Pliva P (2013) Vermicomposting technology as a tool for nutrient recovery from kitchen bio-waste. J Mater Cycles Waste Manag 15:431-439

Hanc A, Szakova J, Svehla P (2012) Effect of composting on the mobility of arsenic, chromium and nickel contained in kitchen and garden waste. Bioresour Technol 126:444-452

Kaushik P, Garg VK (2003) Vermicomposting of mixed solid textile mill sludge and cow dung with the epigeic earthworm Eisenia foetida. Bioresour Technol 90:311-316

Khwairakpam M, Bhargava R (2009a) Bioconversion of filter mud using vermicomposting employing two exotic and one local earthworm species. Bioresour Technol 100:5846-5852

Khwairakpam M, Bhargava R (2009b) Vermitechnology for sewage sludge recycling. J Hazard Mater 161:948-954

Kolar L, Kuzel S, Peterka J, Stindl P, Plat V (2008) Agrochemical value of organic matter of fermenter wastes in biogas production. Plant Soil Environ 54:321-328

Lazcano C, Gómez-Brandón M, Domínguez J (2008) Comparison of the effectiveness of composting and vermicomposting for the biological stabilization of cattle manure. Chemosphere 72:1013-1019

Lee KE (1985) Earthworms, their ecology and relationships with soil and land use. Academic Press, Sydney

Nair J, Sekiozoic V, Anda M (2006) Effect of pre-composting on vermicomposting of kitchen waste. Bioresour Technol 97:2091-2095

Ndegva PM, Thompson SA (2000) Effects of C-to-N ratio on vermicomposting of biosolids. Bioresour Technol 75:7-12

Orozco FH, Cegarra J, Trujillo LM, Roig A (1996) Vermicomposting of coffee pulp using the earthworm Eisenia foetida: effects on C and $\mathrm{N}$ contents and the availability of nutrients. Biol Fertil Soil 22:162-166 
Rehl T, Müller J (2011) Life cycle assessment of biogas digestate processing technologies. Resour Conserv Recycl 56:92-104

Satchel JE, Martin K (1984) Phosphatase activity in earthworm feces. J Soil Biol Biochem 16:191-194

Sharma KS (2003) Municipal solid waste management through vermicomposting employing exotic and local species of earthworms. Bioresour Technol 90:169-173

Sinha RK, Herat S, Agarwal S, Asadi R, Carretero E (2002) Vermiculture and waste management: study of action of earthworms Eisenia foetida, Eudrilus euginae and Perionyx excavates on biodegradation of some community wastes in India and Australia. Environ 22:261-268

Sinha RK, Nair J, Bharambe B, Patil S, Bapat P (2008) Vermiculture revolution: a low-cost and sustainable technology for management of municipal and industrial organic wastes (solid and liquid) by earthworms with significantly low greenhouse gas emissions. In: Daven JI, Klein RN (eds) Progress in waste management research. Nova Science Publishers, New York, pp 158-229
Sinha RK, Agarwal S, Chauhan K, Valani D (2010a) The wonders of earthworms and its vermicompost in farm production: Charles Darwin's friends of farmers, with potential to replace destructive chemical fertilizers from agriculture. Agric Sci 1:76-94

Sinha RK, Herat S, Bharambe G, Brahambhatt A (2010b) Vermistabilization of sewage sludge (biosolids) by earthworms: converting a potential biohazard destined for landfill disposal into a pathogen-free, nutritive and safe biofertilizer for farms. Waste Manag Res 28:872-881

Suthar S, Singh S (2008) Vermicomposting of domestic waste by using two epigeic earthworms (Perionyx excavates and Perionyx sansibaricus). Int J Environ Sci Tech 5:99-106

Tambone F, Scaglia B, D'Imporzano G, Schievano A, Orzi V, Salati S, Adani F (2010) Assessing amendment and fertilizing properties of digestates from anaerobic digestion through a comparative study with digested sludge and compost. Chemosphere 81:577-583

Yadav A, Garg VK (2011) Recycling of organic wastes by employing Eisenia fetida. Bioresour Technol 102:2874-2880 